\title{
Outros olhares sobre o uso da imagem em pesquisa qualitativa: 0 exercício com a interpretação de Didi Huberman
}

\author{
Other perspectives on the use of images in qualitative research: the exercise \\ with the interpretation of Didi Huberman
}

\author{
Otras perspectivas sobre el uso de imágenes en la investigación cualitativa: un \\ ejercicio con la interpretación de Didi Huberman \\ Vânia Lúcia Costa Alves Souza ${ }^{1}$ \\ Vânia Olária ${ }^{2}$ \\ http://dx.doi.org/10.5216/31812
}

\begin{abstract}
Resumo
O trabalho de investigação utilizando imagens como fontes de pesquisa requer o uso de métodos de abordagem que considerem a imagem, o seu simbolismo, o seu contexto histórico, as suas virtualidades e não saberes. Em nossos estudos, consideramos que existem várias possibilidades para a interpretação da imagem, mas que algumas também podem levar o pesquisador a sérios equívocos, pois a sua interpretação pode distanciar-se do contexto histórico presente na imagem; ou podem considerar equivocadamente que os significados da imagem são redutíveis ao método. O objetivo deste artigo é de analisar as interpretações e métodos de análise da imagem de Erwin Panofsky, Pierre Francastel e George Didi-Huberman e refletir sobre as potencialidades do uso da imagem como elemento da pesquisa social em nossas investigações. Com um exercício de análise da imagem, utilizando a interpretação de Didi-Huberman, ressaltamos a compreensão das noções e do preconizado por esse autor, para a análise da imagem e as suas possibilidades na pesquisa qualitativa.
\end{abstract}

Palavras-chave: Iconologia. Iconografia. Dialética da imagem. Espaço simbólico.

\begin{abstract}
The research using images as sources of research requires the use of methods to consider the image, its symbolism, its historical context, its virtues and not knowledge. In our studies, we believe that there are several possibilities for the interpretation of the image, but some may also lead researchers to serious misunderstandings, because its interpretation can distance itself from the historical context in this image ; or may mistakenly consider that the meanings of the image could be reduced to the method. The purpose of this article is to analyze the interpretations and methods of image analysis of Erwin Panofsky, Pierre Francastel and George Didi-Huberman and reflect on the potential of using image as an element of social research. We emphasized the understanding of the concepts recommended by Didi-Huberman for image analysis and its possibilities in qualitative research presenting an exercise using the interpretation of this author
\end{abstract}

Keywords: Iconology. Iconography. Dialectical image. Symbolic space.

\footnotetext{
${ }^{1}$ Doutoranda do Departamento de Geografia na Universidade de Brasília (UnB), mestre em GeoInformation Science, Wageningen University. Brasil, Brasília, DF. E-mail: costa.vania0@ gmail.com

${ }^{2}$ Doutora no Departamento de Educação na Universidade de Brasília (UnB), mestre em Cultura Visual pela Universidade Federal de Goiás (UFG), Brasil, Goiás, Goiânia. E-mail: vania.olaria@ gmail.com
}

Comun. \& Inf., Goiânia, GO, v. 17, n. 2, p. 06-22, jul./dez. 2014 


\section{Resumen}

La investigación que utiliza las imágenes como fuentes de investigación requiere el uso de métodos de acercamiento a considerar la imagen, su simbolismo, su contexto histórico, sus virtudes y no el conocimiento. En nuestros estudios, creemos que hay varias posibilidades para la interpretación de la imagen, pero algunas también pueden llevar a los investigadores a conceptos erróneos graves debido a que su interpretación puede distanciarse del contexto histórico en la imagen; o puede considerar erróneamente que los significados de la imagen se reducen al método. El propósito de este artículo es analizar las interpretaciones y métodos de análisis de imágenes de Erwin Panofsky, Pierre Francastel y George Didi-Huberman y reflexionar sobre el posible uso de la imagen como un elemento de la investigación social en nuestras investigaciones. Con un ejercicio de análisis de imágenes, usando la interpretación de Didi-Huberman, hacen acentuar en la comprensión de los conceptos y recomendado por este autor, para el análisis de la imagen y sus posibilidades en la investigación cualitativa.

Palabras clave: Iconología. Iconografía. Dialéctica imagen. Espacio simbólico.

\section{INTRODUÇÃ̃O}

imagem é um artefato cultural que apresenta e representa o mundo. O termo
imagem se refere às diversas formas visíveis representadas, por exemplo, em
desenhos, fotografias, pinturas, charges. A imagem é um produto que revela a visão de mundo, expressa a sensibilidade e a intencionalidade de seu autor na captura de determinado momento da realidade. "Ela representa as atividades de um grupo social, suas significações específicas o que possibilita a compreensão das ações humanas em determinados momentos históricos.” (SCHIMITT, 2007, p.11).

Por muito tempo a imagem ocupou papel secundário nas pesquisas científicas que privilegiou os documentos escritos. No entanto, o visual e o escrito caminham paralelamente na constituição de grupos sociais, sendo que muitas vezes a imagem é capaz de alcançar mais grupos com as propriedades que a palavra não atinge. (WELLER; BASSALO, 2002, p. 287). A imagem tem signos e significados implícitos associados a uma representação ou imagem mental. A imagem como artefato cultural, "ainda que não seja real, apresenta, representa ou reapresenta o mundo, tornando presente aquilo ou alguém que está ausente" (WELLER; BASSALO, 2002, p. 286).

O caráter "democrático" da imagem a transforma em fonte importante para pesquisa com a sua utilização restrita a especialistas na análise visual. Isto porque a imagem traz dois sentidos embutidos: o objetivo e o subjetivo. O sentido objetivo é dado pela sua própria existência e registro cultural. O sentido subjetivo é dado pela interpretação do sujeito que a observa e interpreta (HERNANDEZ; SCARPARO, 2009). Este sentido subjetivo da imagem torna o seu uso em pesquisas qualitativas desafiador, pois depende da adequada interpretação

Comun. \& Inf., Goiânia, GO, v. 17, n. 2, p. 06-22, jul./dez. 2014 
da imagem, mas que algumas podem levar o pesquisador a sérios equívocos de acordo com a sua leitura distante do seu contexto original. O pesquisador social tem a responsabilidade de aprender as formas de olhar para as especificidades das imagens, buscando a compreensão das suas diferentes simbologias, significados e possibilidades.

Ao utilizar as imagens nas pesquisas qualitativas nos tornamos intérpretes e criadores de sentidos para o material em estudo. Compreendemos que existe a necessidade de combinar a forma de análise da imagem com um método de interpretação. Por exemplo, podemos trabalhar com a Teoria da Iconologia de Panofsky utilizando a interpretação do Método Documentário de Manheim. Este método compreende as visões de mundo de determinados grupos sociais, seus produtos culturais e ações cotidianas como objetos de estudos sociológicos (WELLER; BASSALO, 2002, p. 296). Não é nossa intenção detalhar esse método de análise neste artigo e sim apresentar outro tipo de exercício com a dialética do olhar de Didi-Huberman que nos permite um aprofundamento teórico das atividades desenvolvidas com os professores participantes do Curso de Formação de Professores do Ensino Médio: "Pacto para o Ensino Médio".

O objetivo deste artigo é de apresentar as diferenças de análise de alguns teóricos da imagem; refletir sobre as potencialidades destas interpretações e apresentar um exercício de análise utilizando a interpretação do estudioso Didi-Huberman na compreensão do tema Transdisciplinaridade na escola.

Este artigo apresenta duas partes: Na primeira parte do nosso texto, apresentamos a reflexão sobre a análise da imagem segundo os três estudiosos da imagem: Erwin Panofsky, Pierre Francastel e George Didi-Huberman. Estudamos as suas interpretações de trabalhos artísticos de diferentes épocas, compreendendo as suas específicas formas de lidar com a imagem. Na segunda parte realizamos um exercício dialético de interpretação da imagem e olhar de Didi-Huberman e em seguida concluímos com a reflexão sobre a potencialidade do uso da imagem nas pesquisas sociais.

\section{ANÁLISE DAS IMAGENS: PANOFSKY, FRANCASTEL E DIDI-HUBERMAN}

Os três estudiosos da imagem têm as suas experiências como historiadores da arte. Como nos interessa investigar com imagens, as historiografias das concepções do espaço na história da arte nos são importantes porque consideramos que não se tratam apenas de conquistas artísticas, mas sim, de conquistas do pensamento. Notamos que todos estes autores 
conseguiram avançar na leitura das imagens, realizando abordagens particulares do tempo e espaço simbolicamente representados.

\subsection{Erwin Panofsky: a leitura do visível e do invisível}

Erwin Panofsky nasceu em Hanover em 1882 e faleceu em Princeton, Estados Unidos, em 1968. Ele investigou a iconografia, sendo um representante da Teoria iconológica. O termo iconologia significa 'eikon'- imagem e 'logia'- pensamento. Iconologia para Panofsky significa o estudo cultural de uma obra que traz a representação de um grupo social.

Erwin Panofsky publicou em 1939 uma síntese de estudos de imagens segundo os termos da iconografia e da iconologia. Seu método de análise das imagens é descrito em quatro fases: pré-iconográfica, análise da projeção perspectiva, análise iconográfica e a análise iconológica. (PANOFSKY, 2003).

A primeira fase pré-iconográfica limita-se à observação dos motivos, linhas, cores e volumes da imagem. As pessoas reconhecem os detalhes e descrevem como os percebem, seria "ler o que vemos". A maior parte da descrição dos elementos da imagem provém de uma interpretação de senso comum, acessível a qualquer pessoa.

A segunda fase seria a de ver em perspectiva, compreender as formas simbólicas presentes na imagem. Observando o contexto da imagem, existe sempre a necessidade de nos perguntarmos: "De qual perspectiva se trata"? (PANOFSKY, 2003, p. 115). Ele utiliza a noção de perspectiva como forma simbólica, mais que um estilo, e que se constitui em conteúdos espirituais particulares ligados a signos concretos, intimamente identificados, ou seja, trata-se da visão de mundo também do produtor da imagem.

A terceira fase é a iconografia definida como a descrição e a classificação da imagem. É uma fase carregada de objetividades, descrição dos seus detalhes e também de sua contextualização histórica. A análise iconográfica requer uma familiaridade com os conceitos e temas específicos que podem ser adquiridos por meio de fontes literárias.

A quarta fase é a da iconologia, a partir da qual ocorre a interpretação dos símbolos e sintomas culturais evidenciadas em temas e interpretados pelo pesquisador. Nessa fase a obra é entendida como um documento que evidencia a personalidade do artista ou de uma civilização. Neste momento os elementos selecionados da obra são relacionados com a filosofia, cultura, religião da comunidade da época.

Destacamos a contribuição de Panofsky ao propor a análise da perspectiva em seu texto "A perspectiva como forma simbólica" que foi escrito em 1961(PANOFSKY, 2003). 
Nesta obra ele avançou nos estudos das imagens ao relacioná-las às com questões mais amplas, antes consideradas exteriores e sem importância para o objeto artístico. As análises antigas eram realizadas de forma independente, tão somente com referência a seus elementos constitutivos formais.

A palavra "perspectiva", em Panofsky, tem um significado para além da abordagem técnica. A concepção de perspectiva é ampla, abarca os elementos constitutivos dos objetos individuais como os planos de uma paisagem, sua linha do horizonte e a localização de seus pontos de fuga, revelando o ponto de vista tomado para a composição do quadro, desenho ou fotografia. Assim, quando Panofsky adota, substancialmente, a definição de perspectiva como “intuição perspectiva plena", de Dürer ${ }^{3}$ toma o quadro todo agora não mais como apenas sua superfície material individual isolada, mas como uma 'janela' através da qual vemos um espaço na Figura 1. A imagem, como uma janela ${ }^{4}$, é um plano figurativo para o que vemos e sobre o qual é projetado o espaço unitário, com todas as coisas. Este é um plano com uma perspectiva de Panofsky que significa a visão de mundo de quem olha, observa e analisa a imagem.

Figura 1 - São Jerônimo em seu estúdio.

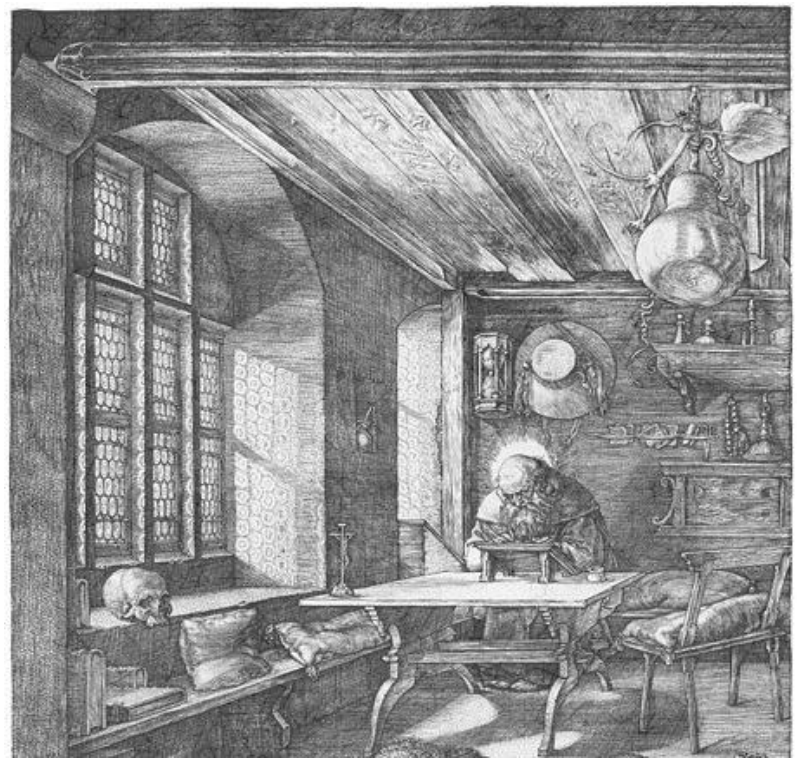

Autor: Albrecht Dürer (1445)

\footnotetext{
${ }^{3}$ Albrecht Dürer nasceu em 1471 e morreu em 1528 em Nurembergue, Alemanha. Ele foi pintor, ilustrador e matemático. Foi famoso artista do Renascimento Nórdico.

${ }^{4}$ Panofsky utiliza a noção de quadro como janela, de Argan. Giulio Carlo Argan nasceu em Turim, em 1909 e morreu em Roma, em 1992. Foi historiador de arte, professor de história da arte moderna na Universidade de Roma e contribuiu com publicações e conferências para o debate artístico, arquitetônico e urbanístico, do século $\mathrm{XX}$.
}

Comun. \& Inf., Goiânia, GO, v. 17, n. 2, p. 06-22, jul./dez. 2014 
Panofsky relaciona a imagem com outros contextos, dialogando com a filosofia, com a ótica e com teoria da arte. Com isso, Panofsky denuncia o que considera como um engano da modernidade: a "perspectiva artificiallis", que procurava formular um sistema aplicável na representação de imagens em superfícies bidimensionais (como no que ainda ocorre nos dias de hoje: a observação de fotografias como 'pranchas planas'), em oposição à "perspectiva naturalis", ou "communis", que inversamente, procurava formular apenas as leis da visão natural. (PANOFSKY, 2003, p. 112). Portanto, a noção de perspectiva como forma simbólica significa que uma perspectiva é mais que um estilo e se constitui de conteúdos espirituais particulares ligados a signos concretos, intimamente identificados.

Panofsky interpretava o espaço como uma representação ideológica, ou seja, a representação do espaço como forma simbólica das conquistas do pensamento, e não apenas artísticas. Francastel avança nesta discussão.

\subsection{Pierre Francastel: a importância do coletivo social}

Pierre Francastel em 1900 e morreu em 1970 também em Paris. Ele obteve o seu reconhecimento acadêmico pelo seu "método sociológico" de análise de imagens.

Francastel, assim como Panofsky, analisa os espaços nas imagens dos objetos de arte como “objetos da civilização". Estes objetos são influenciados pelos seus contextos históricos sociais que o intérprete da imagem não pode prescindir para a compreensão dos seus processos criativos. Contudo, diferentemente do espaço panofskyano, o espaço simbólico de Francastel é condicionado pela história; pelo encontro entre os homens: o coletivo social. A tese de Francastel demonstra que não são os tratados teóricos que oportunizam a invenção de novos espaços, mas sim, estes é que são materializações de novas mentalidades e condutas da sociedade. Francastel realizou estudos comparativos e epistemológicos com os espaços perceptivos do Renascimento, o espaço óptico-sensorial do Impressionismo e o espaço polivalente da Arte Contemporânea.

Partimos da afirmação de Panofsky (2003, p.124) de que a reforma de uma prática só pode ser concebida no momento em que já se conhece a construção sistemática da mesma. Com um pensamento contrário ao de Panofsky, em "Pintura e sociedade" Francastel (1990) chama a atenção para o fato de que Brunelleschi ${ }^{5}$, mesmo sendo considerado o inventor do

\footnotetext{
${ }^{5}$ Filippo Brunelleschi nasceu em 1377 e morreu em 1446 em Florença, Itália. Ele foi arquiteto e escultor renascentista. Em seus trabalhos ele restabeleceu na prática o conceito do ponto de fuga das perspectivas linear.
}

Comun. \& Inf., Goiânia, GO, v. 17, n. 2, p. 06-22, jul./dez. 2014 
Renascimento, na verdade encontrou uma questão já colocada e anterior a ele: o que fez foi dedicar a grande obra de sua vida "à resolução de uma dificuldade legada pelas gerações que o precederam" (FRANCASTEL, 1990, p. 9). Francastel demonstra que não são os tratados teóricos que colocam um problema a solucionar, por exemplo, com a compreensão de que as inovações renascentistas eram preocupações caras à própria prática popular entre os artistas e que a admiração pelos antigos, por exemplo, não foi interesse apenas de teóricos como Brunelleschi, mas de descobertas fundadas em longas experiências desde muitos séculos:

[...] a importância atribuída às relações concretas e mensuráveis que existem entre objetos aparentemente distanciados e estranhos uns aos outros, a descoberta do fato de que as linhas não definem apenas os limites das superfícies contínuas, mas que a intersecção dos planos se prolonga e se projeta no vazio, dando-lhe uma forma, constituem decerto uma lição preciosa para os pintores. Brunelleschi, ele mesmo, não é de forma alguma um pintor [grifo nosso] (FRANCASTEL, 1990, p. 11).

Compreendemos com Francastel a noção de que os espaços são, antes de tudo, materializações das condutas e mentalidades, para, só depois, se tornarem tratados teóricos correspondentes sejam construídos e, muitas vezes até terem os seus significados reduzidos. Tal noção é tomada para nossas investigações como uma pedra de toque, influenciando nossas interpretações e compreensões com imagens. Por exemplo, a noção de Francastel de que os artistas do Renascimento projetaram uma cidade ideal em suas obras, mas que só seriam construídas posteriormente, nos leva a considerar uma dialética presente-passado-futuro para as imagens, vez que estas tratam de uma realidade social que é figurativa, isto é, uma realidade imaginária, dos sonhos e do futuro de um coletivo social. Acreditamos que possa ser por isso que o pensamento de Francastel é chamado de "método sociológico", vez que não encontramos essa expressão cunhada pelo próprio autor, em seus textos. O que podemos encontrar nos textos desse autor são suas noções sobre as relações sociais nas concepções de espaço, o que não podemos considerar como 'métodos', por não reduzirem-se às descobertas de novas técnicas. Para, além disso, a concepção do espaço em Francastel demonstra a "existência de determinadas e reveladoras leis do espírito e de ideais, sendo que as técnicas não são criadas em virtude de uma lei da natureza, mas de uma opção estético-social deliberada" (FRANCASTEL, 1990, p. 20).

Para a superação do método perspectivo de Panofsky, consideramos também a crítica que Francastel (1990, p. 23) faz a Giulio Carlo Argan, o qual influenciou o pensamento de Panofsky. Segundo Francastel, a perspectiva moderna de representação 'verdadeira' dos

Comun. \& Inf., Goiânia, GO, v. 17, n. 2, p. 06-22, jul./dez. 2014 
espaços é uma ideia fundamental na qual repousa uma interpretação falsa das obras e da história, ver o espaço como uma categoria kantiana do pensamento.

Mesmo quando Argan escreve que a perspectiva não é uma lei constante do espírito humano, mas um momento da história das ideias sobre o espaço, ele parece admitir que esse espaço possua, para toda a humanidade, uma espécie de permanência, já que são apenas os modos de notação que mudam. É chegado o momento em que essa colocação do problema já não parece aceitável. Se quisermos igualar nossa crítica aos trabalhos dos estudiosos e dos artistas contemporâneos, teremos de mudar radicalmente de ponto de vista. (FRANCASTEL, 1990, p. 23).

As concepções de espaço são fundamentais para as práticas que empreendemos com análises de imagens, em nossas pesquisas, hoje. Buscando uma interlocução entre autores, intentamos uma maior compreensão da 'janela arganiana' de Panofsky para análises das imagens. Com essa metáfora esse autor nos chama a atenção para a visão de mundo e para elementos antes considerados 'exteriores' à imagem, mas que influenciam diretamente em suas interpretações. Contudo, adiantando a crítica que Didi-Huberman desenvolve de forma mais aprofundada à Panofsky, "de que este apenas abre rapidamente a porta para a entrada de um frescor para, imediatamente, fechá-la novamente" (DIDI-HUBERMAN, 1990, p. 7). Francastel (1990) considera que a 'janela' da adoção do sistema de representação 'verdadeiro' da perspectiva linear - ou da perspectiva curva panofskyana, acrescentamos nós - encerra as imagens em "uma espécie de universo reduzido", aprisionando-as com as leis da física da óptica (FRANCASTEL, 1990, p. 22).

A proposta de Francastel é de ver as imagens não somente em sua forma descritiva, e sim em suas realidades estéticas tentando reconstituir o passado. Ele trata espaço não como uma realidade em si, da qual somente a representação é variável segundo as espécies. O espaço é a própria experiência do homem e este percebe estes espaços em diferentes fases.

A primeira fase revela a visão do mundo de forma topológica, isto explica o fato de sermos sensíveis, inicialmente, a determinadas categorias de obras abstratas, a determinadas formas, aparentemente estranha à nossa experiência comum de indivíduos moldados e modificados por uma cultura popular.

A segunda fase da representação espacial é aquela em que se percebe um mundo mais distinto, desprovido de qualquer escala permanente e abstrato de medida com uma visão projetiva do espaço.

A terceira fase corresponde à descoberta das relações puramente lógicas e das relações assimétricas e de todo sistema de codificação que repousa os postulados de Euclides

Comun. \& Inf., Goiânia, GO, v. 17, n. 2, p. 06-22, jul./dez. 2014 
e que servem de base para a ciência, para a vida afetiva e imaginativa. Aquilo que se chama de visão "normal" é apenas uma visão selecionada e que o mundo é infinitamente mais rico de aparências (FRANCASTEL, 1990).

Concluímos que a realidade não é apenas iconológica, panofskyana, mas é também figurativa, ou seja, nós selecionamos algumas coisas da realidade e sonhamos com outras, em seus devires sociais para a criação do novo. Para Francastel, a análise sociológica deve considerar também o imaginário para as imagens das obras de arte e para as imagens em geral; e diríamos nós: também para as imagens da cultura visual, na qual os educadores e as pessoas em geral, hoje em dia, estão imersas. Por sua vez, a função figurativa para a construção de conhecimentos com as realidades também pode elaborar o pensamento de forma direta e não lhe são necessárias traduções para categorias verbais. Evidentemente, essa desnecessidade e a impossibilidade de tradução para o verbal (racional) do sentido das imagens se contrapõem a uma epistemologia científica moderna.

Consideramos a importância também da dialética de Francastel para as análises de imagens, pois acreditamos que os objetos de nossas pesquisas também transitam entre o mundo real, o percebido e o imaginário. Tais noções são mais bem investigadas por DidiHuberman, com o qual passamos a dialogar, com este texto.

\subsection{Georges Didi Huberman: a irredutibilidade do figurativo a legíbilidade tradicional do visível ou invisível}

Georges Didi-Huberman nasceu em Saint-Etiénne, França, em 1953. É filósofo, historiador e crítico de arte, leciona Antropologia Visual, na Escola de Altos Estudos em Ciências Sociais em Paris. Didi critica a limitação da historiografia da arte e contesta a sua tradição iconológica de dar conta apenas do visível através de uma abordagem "científica" da história da arte. Inspirado pelas teorias da psicanálise de Freud e Lacan, da fenomenologia de Merleau Ponty e filosofia Walter Benjamin, ele apresenta a compreensão da imagem através da dialética do olhar.

A hipótese trabalhada por Didi é que a história da arte deveria enterrar as problemáticas do visual e do figurável, dando novos fins às imagens da arte, fins que colocavam o visual sob a tirania do visível (e da imitação) e o figurável sob a tirania do legível (e da iconologia). Panofsky e outros buscavam sustentar a eficácia do sistema de análise que configuravam em leituras unificadas dos objetos artísticos, desconsiderando a sua complexidade. Didi defende a "omnitradubilidade da imagem", ele condena a sujeição do

Comun. \& Inf., Goiânia, GO, v. 17, n. 2, p. 06-22, jul./dez. 2014 
visível ao lugar, a pretensão de esgotar a leitura e apreensão da imagem a partir do código oriundo exclusivamente do discurso verbal.

Didi nos instiga a analisar a imagem com cuidado, exorcizá-la e desmembrá-la identificando as suas mensagens ambíguas, plurais e históricas.

$\mathrm{O}$ ato de ver não é o ato de uma máquina de perceber o real enquanto composto de evidências tautológicas. $\mathrm{O}$ ato de ver não é o ato de dar evidências visíveis a pares de olhos que se apoderam unilateralmente do dom visual para se satisfazer unilateralmente com ele. Dar a ver é sempre inquietar o ver, em seu ato, em seu sujeito. Ver é sempre uma operação de sujeito, portanto uma operação fendida, inquieta, agitada, aberta. Entre aquele que olha e aquilo que é olhado. (DIDI-HUBERMAN, 1998,77)

Didi sugere a categoria do invisível para além do visível e do legível da imagem. A categoria visível trata daquilo, que no método panofskyano, é objeto da leitura préiconográfica. O legível pode ser identificado à leitura iconológica. Porém a síntese iconológica não pode ser identificada à categoria do invisível. Didi sugere trabalhar o invisível a partir da abertura do olhar. Ele defende a problematização da questão do olhar do historiador que apreende o visual da imagem, o visível, o legível, o invisível e o virtual (Figura 2).

Este cuidado na análise da imagem revela duas atitudes importantes para estabelecer a dialética do olhar: Ver e Olhar. Ver em um exercício tautológico, ver apenas o que está exposto, reflete a relação do historiador com a obra em uma atitude não cientificista. Olhar em uma atitude de crença em ver alguma coisa além, se distanciar do objeto e romper o paradigma sujeito-objeto defendido por Panofsky. A categoria do invisível revela a eficácia simbólica da obra, seria o caráter intangível da arte. O paradoxo da imagem para Didi é manifestado por este cuidado no olhar e a identificação do sujeito que observa a imagem: o homem de crença e o homem tautológico reunidos em um só.

Figura 2 - Dialética do olhar de Didi-Hubermann

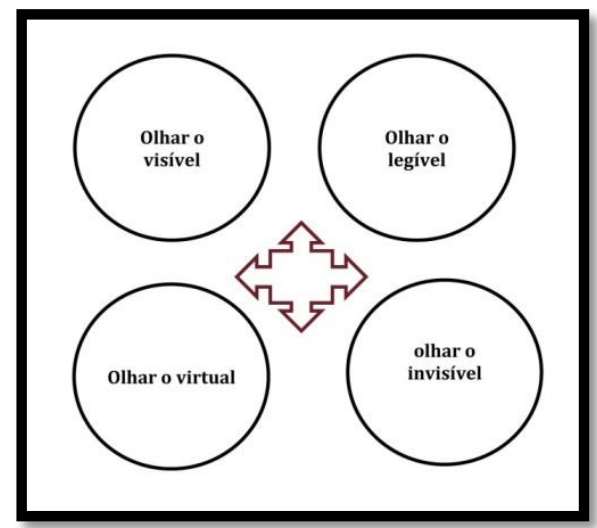


Se a imagem, a obra de arte, tem uma mensagem ambígua, plural, como produzir conhecimento histórico sobre estes objetos artísticos?

A imagem nos exige falar da clareza e da obscuridade, da sua dialética no mostrar. Os movimentos de olhar e suspender o olhar da imagem nos permite a revelação da imagem. A eficácia da imagem não se deve somente à transmissão do conhecimento visual, legível, invisível, mas ao não conhecimento transmitido. Esta é a dialética do conhecer e do não conhecer (saber e não saber) que a historiografia da arte, baseada na iconografia, ignora ao esgotar a finalidade da arte na vitória do conhecimento. Segundo Didi (1990), Panofsky não entendeu que a imagem requer a compreensão da sua dialética, clareza e obscuridade e não a sua abordagem racionalista do esclarecimento e desmembramento da imagem. Panofsky compreendeu a dialética da imagem, porém a exorcizou.

Devemos respeitar, compreender, reler as teorias de Panofsky. Graças a Panofsky aprendemos que a história da arte se prendeu a teorias que não nos revelam a dialética do saber e não saber. Ao nos conscientizar desta dialética, temos que nos habilitar a ver o possível e o impossível da imagem, compreender a imagem e as suas dialéticas. (DIDI-HUBERMAN, 1990,16).

A imagem real só existe em seu momento. A imagem é anacrônica. O historiador só tem o objeto, o documento e não o seu contexto, o lugar de sua existência. Didi nos convida a ver a imagem na dialética do sintoma e da crise, um olhar que nos permita, num só golpe, apreendermos a estrutura e o abalo da imagem. Panofsky tenta decifrar a imagem, perseguir os seus significados, simbolismos em um exercício de redução do potencial crítico da imagem. Panofsky ignora a dialética da imagem. Didi nos alerta: "É preciso ter cuidado. A imagem se revela sua análise não pode ser fechada, teleológica" (DIDI-HUBERMAN, 1990, p176).

\section{ANALISE E INTERPRETAÇÕES DE UMA IMAGEM}

Os estudos sobre a análise da imagem nos mostraram a importância de considerar o contexto histórico nas interpretações. Segundo Ginzburg (1989) é o contexto que decide se é necessário introduzir nas análises elementos de controle externos às criações artísticas.

Interpretamos uma imagem que foi produzida no ambiente de discussão sobre Transdisciplinaridade, desenvolvida no curso de formação de professores. Em nosso exercício reflexivo trabalhamos com um desenho realizado por um professor de Geografia de uma escola de Ensino Médio de Brasília. Este professor é cursista do curso de formação "Pacto 
Nacional pelo fortalecimento do Ensino Médio", PNEM, que desenvolve reuniões semanais nas escolas.

O curso de formação para os professores, "Pacto Nacional pelo fortalecimento do Ensino Médio", PNEM, é um acordo entre o MEC e as Secretarias Estaduais e Distritais de Educação com o compromisso de valorização continuada do professor e coordenador pedagógico do Ensino Médio e busca melhorar as práticas pedagógicas na escola. O Pacto envolve ações com objetivos descritos no artigo $3^{\circ}$ :

Art. $3^{\circ}$ As ações do Pacto têm por objetivos:

I - contribuir para o aperfeiçoamento da formação dos professores e coordenadores pedagógicos do Ensino Médio;

II - promover a valorização pela formação dos professores e coordenadores pedagógicos do Ensino Médio;

III - rediscutir e atualizar as práticas docentes em conformidades com as Diretrizes Curriculares Nacionais do Ensino Médio - DCNEM. (DOU, 2013)

Uma das reflexões do curso é sobre as formas de mudanças na estrutura escolar para que esta se torne atraente para os jovens. Uma proposta trabalhada, neste primeiro semestre foi a reestruturação curricular. No Distrito Federal, desde 2007, existe a versão experimental do Currículo em Movimento (SEEDF, 2013) já executado em algumas escolas e com avaliações e debates em Conferências de Educação. O Currículo em Movimento/ SEEDF reforça a formação continuada do professor agora com o reforço do PNEM. O Currículo em Movimento/ SEEDF trabalha com os seguintes objetivos:

"Os objetivos específicos deste currículo são:

- Melhorar as condições pedagógicas por meio da reorganização do tempo/espaço do cotidiano.

- Reduzir os índices de reprovação e evasão escolares.

- Tornar mais efetiva a relação professor-estudante.

- Qualificar a avaliação, incluindo o processo contínuo de recuperação das aprendizagens.

- Redimensionar a coordenação pedagógica como um espaço/tempo de planejamento, troca de experiências, pesquisa e formação continuada dos professores" (SEEDF, 2013).

O Currículo em Movimento trata os conhecimentos das disciplinas como complementares e relacionados em um movimento dialético de construção e diálogo. Os espaços de formação dos professores seriam os espaços onde a estruturação e a organização dos conhecimentos seriam construídos coletivamente. 
O tema transdisciplinaridade foi debatido em um encontro com os professores. A transdisciplinaridade trabalha com a dinâmica geradora de ação de vários níveis da realidade ao mesmo tempo. Trans significa que o objeto estudado está ao mesmo tempo entre as disciplinas, se realiza através da disciplina e além da disciplina. Nesta abordagem a realidade se apresenta em diferentes níveis de complexidade, num movimento dialético que por um momento está presente e em outro momento aparecer estar além (BASARAB, 2000, p 11).

O enunciado da proposta do exercício foi para que os professores se imaginassem como construtores de uma nova escola e doadores de materiais para isso. Eles desenharam e ao final colaram seus desenhos em um quadro à frente e apresentaram suas ideias para os seus colegas. $\mathrm{O}$ tema foi amplamente debatido utilizando a linguagem visual como principal forma de expressão.

Destacamos o desenho deste professor para a nossa interpretação dialética da imagem no contexto da transdisciplinar idade na escola (Figura 3). Entendemos que este desenho revela muito mais do que foi discutido no curso. Pedimos autorização de uso do desenho para o professor e avançamos na interpretação dialética da imagem sob o olhar de Didi-Hubermann.

Figura 3 - Sem Título

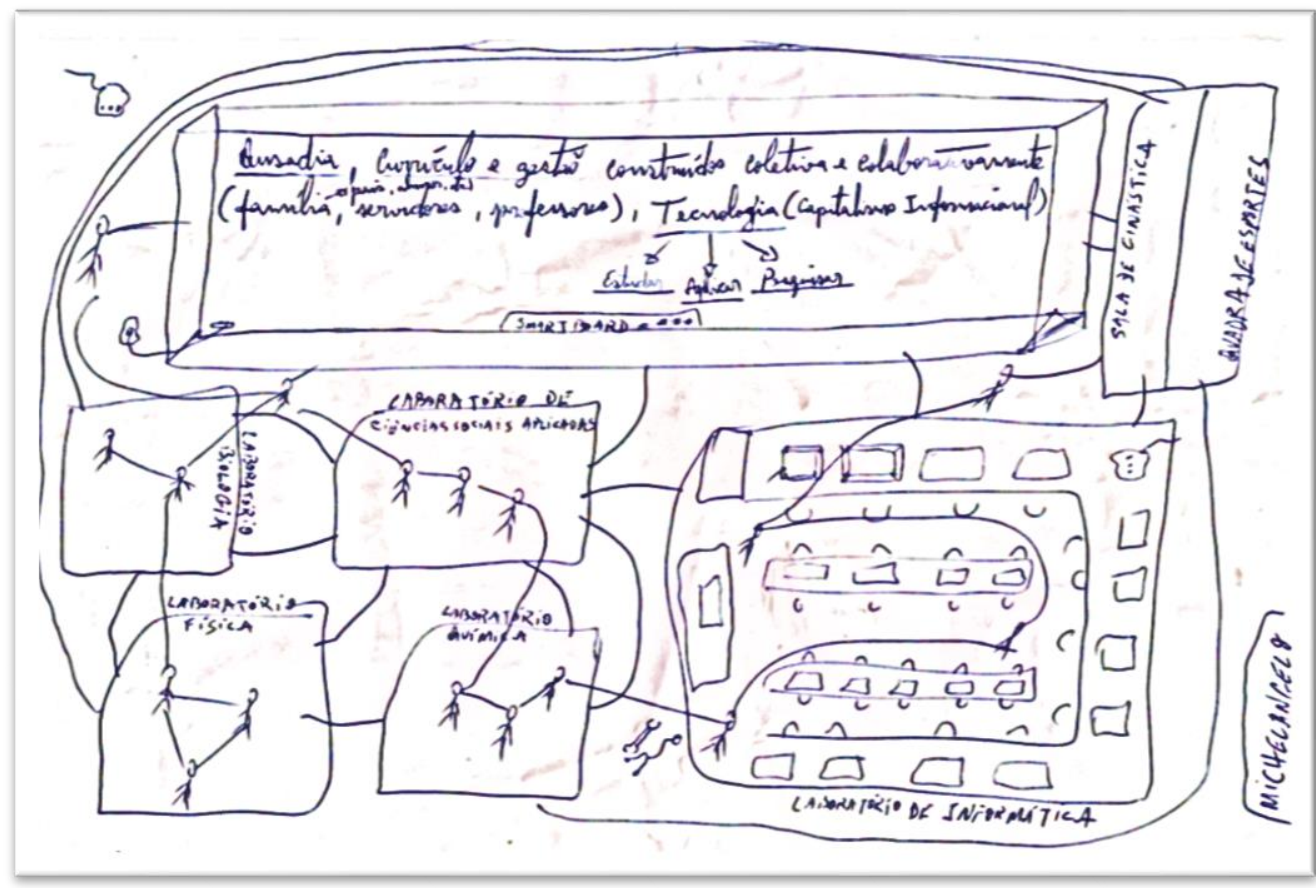

Autor: LIMA, 2014. 
Utilizando a interpretação dialética do olhar de Didi, iniciamos a nossa análise com leituras em camadas: Uma primeira camada interpretativa para a imagem, aqui em questão, foi de uma camada objetiva e fria na qual o professor, autor da imagem, compõe o espaço para a escola de seus sonhos. Esta primeira leitura nos inquietou.

Descamando-a podemos nos deixar olhar para uma possível busca de uma integração curricular - justamente e contraditoriamente - no formalismo dos quadrados das linhas retas que só aparentemente mantém as compartimentalizações para as diferentes disciplinas. As linhas retas intelectuais e os títulos sínteses podem orientar-nos para a visualização de uma escola, a ser concretizada em um futuro próximo, já assinalado com as muitas curvas sinuosas lutando para carregar alunos, professores e conhecimentos a ocuparem os mesmos espaçostempos. Estamos convictas de que essas curvas e semi-curvas não dão conta disso. Contudo uma camada virtual e futura já se faz presente, só ainda de forma latente porque esta representação continua presa em modelos científicos mecânicos clássicos, conhecimentos limitados justificando a nossa dificuldade para defender os novos espaços-tempos.

A imagem demonstra, antes de configurar-se, possivelmente, inelutável e sem medo, a compreensão virtual de um mundo e uma escola em que tudo é visto como interligado; está e não está; é e não é de acordo com o princípio do terceiro incluído de um novo tipo de conhecimento: a transdisciplinaridade. (BASARAB, 2000, p24).

Com tal interpretação, contrapomo-nos às percepções e discursos políticos administrativos de que os professores de Brasília não estão preparados e não são capazes de realizarem integrações curriculares e, mesmo, a transdisciplinaridade na escola. Consideramos que tais transformações já podem estar em curso.

Contudo continuamos precavidas e sentimos que o saber sobre essa imagem anda de mãos dadas com o não saber, como preconiza Didi-Huberman. Por exemplo, o professor autor da imagem parece alinhar-se com um capitalismo informacional para as tecnologias, assim definida por ele e tão presentes e necessárias para sua escola imagética. Em uma abordagem transdisciplinar com a escola, como poderíamos subverter as racionalidades da ciência e suas tecnologias em favor das espiritualidades e emancipações humanas? Percebemos estas questões no desenho.

Assim, nossa busca metodológica pauta-se por excelência em um fazer junto, impulsionando-nos a estar sempre em contato com nossos sujeitos, em idas e vindas espirais (re) interpretativas, com o objetivo de alcançar as mudanças, as transformações e a realização

Comun. \& Inf., Goiânia, GO, v. 17, n. 2, p. 06-22, jul./dez. 2014 
dos sonhos que queremos com a escola. Trata-se de interpretações abertas aos sujeitos, nesse caso o professor-autor protagonista dessa investigação e também a você, leitor/a, pois a nossas interpretações estão inconclusas, parciais e inevitavelmente incompletas, carentes de outras, complementares, para as construções da escola que queremos.

\section{CONSIDERAÇÕES FINAIS}

Muitos são os desafios para o estudo das imagens. É importante compreender que todas as imagens têm a sua razão de ser e de existir, exprimem e comunicam sentidos, estão carregadas de valores simbólicos e cumprem várias funções sejam religiosas, políticas ou ideológicas.

Ao analisar as imagens, buscamos construções de sentidos e concordamos com o defendido por Didi-Huberman de que apenas as análises iconológica e sociológica tradicionais não dão conta de sua totalidade como imagem. Para nossas interpretações, consideramos não usar a razão imoderadamente; intentamos emprestar-lhes sentidos, buscando por suas virtualidades e futuros nos rastros sintomáticos deixados em si por seu autor em seu contexto de criação.

O exercício da análise da imagem nos requer a proximidade com o autor da imagem, o direito às interpretações inacabadas, porém importantes para a compreensão da realidade estudada. As pesquisas qualitativas utilizando imagens podem representar modos particulares de expressão dos sujeitos envolvidos na pesquisa, enriquecendo a abordagem do tema pesquisado.

Em nosso exercício aprendemos que a imagem, logo seu assunto (conteúdo), nos parece muito claro. Algumas pessoas até afirmam que uma imagem vale por mil palavras porém, um paradoxo nos atinge: quando lemos a imagem, algo ainda nos perturba: sentimos que não sabemos tudo sobre ela. Na verdade, nós sentimos que ver não é tão simples assim e que uma imagem não vale nem mesmo por uma só palavra, pois imagem e palavras não são equivalentes. Diante dessa ambivalência das imagens e na busca de dominá-la, podemos escolher dois caminhos na imagem:

1. fazer uma leitura transcendente utilizando um modelo de alguma crença. Desta forma podemos afirmar a existência de alguma outra coisa além do que estamos vendo, referendando assim nossa interpretação particular.

2. afirmar que o que vemos, afinal de contas, é só o que vemos. Inscrever o visível, de uma vez por todas, no circuito fechado dessa linguagem e referendando um regime de tautologia. 
Diante de tais regimes, considerados insatisfatórios por nós, buscamos aproximações com as imagens, por meio de análises formais e também por meio de análises simbólicas, inserindo-as na cultura. Entretanto, consideramos o risco de fechá-la em uma única estrutura e não vermos o potencial revolucionário das imagens em geral. Sendo assim, defendemos, sobretudo, a pertinência epistemológica de considerar as possibilidades de dar outros sentidos para as imagens.

Em movimentos dialógicos, podemos nos abrir um pouco mais para a construção de conhecimentos com as imagens, considerando suas virtualidades e a sua possibilidade de figurar e construir o futuro. Francastel, por exemplo, afirma que o imaginário põe em xeque a cultura aceita, fazendo do espaço um instrumento de revolução permanente. Didi-Huberman vai um pouco mais longe e afirma que não devemos reduzir o objeto para que caiba no método. É preciso deixar espaço, no método, para que as contradições representadas pela imagem se revelem, pois mesmo depois de todas as nossas análises, as imagens insistem em ser mais... Em exibir e nos propor um mistério, em diálogo com nosso olhar...

"Viajamos" pela imagem porque vagamos solto/as, a sua dimensão conduz o nosso olhar de um lugar para outro... Porque a trespassamos, vendo algo que está ali e não está, ou seja, está ali em potência, e por isso em flashes simultâneos de significados, sem fim. Algo inacabado e se atualizando em conhecimentos e não conhecimentos, pois o saber e o não saber andam de mãos dadas, conforme o demonstrado por Didi-Huberman. Agora, quando reconhecemos esse caráter de sujeito, para a imagem, respeitando-a em seus mistérios, é o desconhecido que nos olha...

\section{REFERÊNCIAS}

BASARAB, Nicolescu. Educação e transdisciplinaridade. Brasília: UNESCO, 2000.

DIDI-HUBERMAN, Georges. O que vemos e o que nos olha. Campinas: Editora 34, 1998.

DIDI-HUBERMAN, Georges. Confronting Images: questioning the Ends of a Certain History of Art. Pennsylvania: Les Editions de Minuit, 2004.

BRASIL. Portaria n. ${ }^{\circ}$ 1140, de 22 de novembro de 2013. Institui o Pacto Nacional pelo Fortalecimento do Ensino Médio e define suas diretrizes gerais, forma, condições e critérios para a concessão de bolsas de estudo e pesquisa no âmbito do ensino médio público, nas redes estaduais e distrital de educação. Diário Oficial da União, Brasília, DF, 9 dez. 2013. Seção 1, p. 24-25.

BRASÍLIA, DF. Secretaria de Estado da Educação do Distrito Federal (SEEDF). Currículo em Movimento da Educação Básica. SEEDF; GDF, Brasília, 2014. Disponível em: <http://www.se.df.gov.br/materiais-pedagogicos/curriculoemmovimento.html>. Acesso em: 13 nov. 2014.

DÜRER, ALBRECHT. São Jerônimo em seu estúdio. 1521. Pintura. 


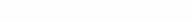

FRANCASTEL, Pierre, Pintura e Sociedade. São Paulo: Martins Fontes, 1990.

GINZBURG, Carlo. Mitos, Emblemas, Sinais: morfologia e história. São Paulo: Companhia das Letras, 1989.

HERNANDEZ, Aline; SCARPARO, Helena. Silêncios e Saberes Guardados nas Imagens do PréGolpe de 1964. Revista de Psicologia Política, São Paulo, v.8, n. 15, abril de 2009. Disponível em: < http://www.fafich.ufmg.br/ psicopol/seer/ojs/viewarticle. php?Id=139>. Acesso em: 01 de nov. de 2013.

PANOFSKY, Erwin. A perspectiva como forma simbólica. In: História da arte italiana: da Antiguidade a Duccio. Tradução de Wilma De Kantinszky. São Paulo: Cosac e Naify, 2003.

SCHIMITT, J. O corpo das imagens: ensaios sobre a cultura visual na Idade Média. São Paulo: Edusp, 2007.

WELLER, Wivian; BASSALO, Lucélia de M. Braga. Imagens: documentos de visões de mundo. Sociologias, Porto Alegre, ano 13, n. 28, set./dez. 2011.

Recebido em: 07/09/2014

Aceito em: 30/09/2014

Publicado em: 10/12/2014 